Šeit minềtäs problēmas nébūt nav visas, taču jācer, ka skolotājiem, kopīgi ar ministriju sastrādājoties, radīsies sistēma, kā racionāli veikt šo visiem cittautiešiem nepieciešamo darbu.

\title{
VAI VIDES SPECIĀLISTI SPĒJ NODROŠINĀT VIDES AIZSARDZÏBU?
}

\author{
MĀRIS OSIS \\ Latvijas Skolotāju savienība \\ Brīvības gatve 470 - 2, Rīga, Latvija, LV - 1056 \\ T.: 7374920
}

Vides centrā atrodas cilvēks ar savām kvalitātēm vai patologijām, kas kā sabiedrības sastāvdaļa ietekmē Vides kvalitāti. Latvijas valsts nedrīkst būt vienaldzīga, liberāla, ja tās dzīves telpā pēc inerces turpinās bijušās PSRS (kuru ASV prezidents R.Reigans nosauca par "L̦aunuma impēriju") ideoloǵijas kultivētais materiālisms, ekonomikas solutizēšana un cīna ar "buržuäzisko nacionālismu".

Eiropas Padomes izveidotā neatkarīgo ekspertu darba grupa savā zinojumā uzsver: "Vides kultūras dimensijas ignorēšana ir viena no visnopietnākajām Eiropas valstu politikas kḷūāam, jo savas kultūridentitātes apzināšanās ir lielākais virzītājspēks vides mantojuma aizsargāšanā, vienlaicīgi attīstot sociālo un ekonomisko potenciālu". Ekspertu grupa iesaka to, kas Latvijā ir ticis istenots pirms Maskavas 1940.g. 17.jūnija okupācijas Vispārējo Latgales Dziesmu Svētku laikā Daugavpilī - "Skolas ir jāpārvērš par kultūrvides centriem, kas savukārt nosaka nepieciešamību pašos pamatos pārvērtēt skolotāju sagatavošanu". ... "Kultūra ir îpaši svarīga tieši ekonomisko grütību periodā noziedzību veicinošas vides pārveidošanā, jauniešu izraušanā no kriminogēnās vides, lai vēläk nevajadzētu tērēt lielus finansiālus resursus, labojot sabiedribas vainas, ko rada bezdarbs, pilsētu un lauku apvidu pagrimums un sociālā atstumtība". Vispasaules kultūras un attīstības komisijā par intelektuâlās atjaunotnes un cilvēces attīstības galveno avotu tiek uzskatīta kulturālu cilvēku sabiedrība: "Tã ir kultūra, kas dod cilvēkam iespēju pārdomāt savu rīcību, kritiski spriest ar morālas atbildības sajūtu". Vides kopēji, vides aizsargi ar kultūras dimensijas akcentu tiek sagatavoti Norvéǵijā - dabas inspektori Blekkulfs vecumā no 4-14 gadiem un kuru kopskaits pārsniedz 20000 . Ziemeļu Ministru padome 1997.g. Parīzē bija sarikojusi konferenci "Norden un Eiropa" - par Ziemelvlstu vides un identitătes iespējām izdzìvot starpnacionālo korporāciju invāziju laikā, kas spiež uz vides, darba u.c. aizsardzības prasību samazināšanu un ekonomiskās atkarības palielināšanu.

Latvijā trīsdesmitajos gados kultūras dimensiju uzturēja, vidi izkopa un aizsargāja 68000 lielā aizsargu organizācija, ko šodien Latvijā nespēj aizvietot zemessargi, cietumsargi, miesassargi un citi sargi. Latvijas samazinātā atkarība no citām valstīm un videi draudzīga saimniekošanas prasme deva iespēju izvairīties no Vispasaules ekonomiskās krīzes un deponēt ārzemēs $10607,217 \mathrm{~kg}$ zelta. (Latvijas Bankā esošais zelts, valūta 20 milj. vērtībā naktī no 12. uz 13.jūliju 1940.gadā tika aizvesta uz Maskavu.) 